\title{
Percepcija lica u poremećaju iz spektra autizma: Od singularnih prema modularnim perspektivama
}

\author{
Ana Miličević i Vito Bošnjak, \\ Sveučilište u Zagrebu, Medicinski fakultet, Zagreb, Hrvatska
}

Mirta Stantić

Sveučilište Oxford, Odsjek za eksperimentalnu psihologiju, Oxford, UK

\begin{abstract}
Sažetak
U posljednjih se desetak godina u medijima često govori o povećanom broju dijagnosticiranih slučajeva autizma u djetinjstvu. U ovom sustavnom pregledu razmatramo razvoj razumijevanja percepcije lica, jedne od specifičnijih značajki autizma, u svjetlu komorbiditeta s aleksitimijom i uznapredovalih statističkih metodologija istraživanja. Navodimo literaturu koja se bavi percepcijom lica $\mathrm{u}$ autizmu u različitim kognitivnim zadacima i upućuje na važnost često komorbidne aleksitimije, kao i literaturu koja koristi neuroslikovne metode istraživanja i potvrđuje važnost različitih uzoraka gledanja u autizmu pri analizi rezultata. U svrhu poboljšane obrazovne i socijalne integracije osoba s autizmom i/ili aleksitimijom predlažemo teme za daljnje istraživanje.
\end{abstract} amigdala

Ključne riječi: autizam, aleksitimija, percepcija lica, vizualna percepcija, fuziformni girus,

\section{Autizam}

Spektar autističnih poremećaja (PSA) uključuje neurološke razvojne poremećaje okarakterizirane teškoćama u socijalnim interakcijama te verbalnoj i neverbalnoj komunikaciji, kao i neuobičajenim ponašanjima te ograničenim aktivnostima i interesima (Američka Psihijatrijska Udruga, 2014). Na temelju dijagnostičkih markera autizma propisanih priručnikom DSM-IV Američke psihijatrijske organizacije relevantne udruge navode da u Hrvatskoj živi oko osam tisuća osoba s autizmom (Savez udruga za autizam Hrvatske, 2020).

Premda dijagnostički markeri autizma ne uključuju atipičnu percepciju identiteta, već samo emocija, poteškoće s percepcijom češće su u populaciji osoba s

Mirta Stantić, Department for Experimental Psychology, University of Oxford, New Radcliffe House, Walton Street, Oxford OX2 6BW, United Kingdom. E-pošta: mirta.stantic@psy.ox.ac.uk 
autizmom nego u neurotipičnoj populaciji (Simmons i sur., 2009; Webb, Neuhaus i Faja, 2017). Pretpostavlja se da su mnoge socijalne teškoće u autizmu posljedica poremećaja u vizualnoj percepciji. U ovom preglednom članku razmatramo eksperimentalne metode koje su poboljšale razumijevanje teškoća prilikom percepcije lica u autizmu. Bavimo se specifično i aleksitimijom, supkliničkim komorbiditetom okarakteriziranim problemima s percepcijom vlastitih $\mathrm{i}$ tuđih emocija, koji često prati dijagnozu autizma. Na kraju predlažemo smjerove daljnjeg istraživanja u svrhu poboljšanja socijalne integracije djece i odraslih s autizmom.

\section{Važnost percepcije lica i emocija}

Percepcija lica, jedna od najosnovnijih vizualnih i socijalnih vještina koju posjedujemo, omogućuje nam da u roku od nekoliko stotina milisekundi procijenimo je li nam netko poznat ili nepoznat i potencijalno opasan, je li dobro ili loše raspoložen, jesmo li u rodu itd. Premda nizovi istraživanja pokazuju kako percepcija lica utječe na razne iznimno važne odluke koje donosimo, recimo to za koga glasamo ili kako se odobravaju krediti (Ballew i Todorov, 2007; Sussman, Petkova i Todorov, 2013), u ovom se članku fokusiramo na temeljna pitanja percepcije identiteta i emocija iz lica u sferi vizualnih istraživanja. Naime, kognitivni procesi koji nam omogućuju normalno funkcioniranje u svakodnevnim interakcijama često zahtijevaju sasvim rudimentarnu percepciju identiteta i emocija, za razliku od složenih integracija podataka potrebnih za donošenje kompleksnijih socijalnih odluka (poput političkih izbora ili odluka o kreditnoj sposobnosti).

Možda je važnost uspješne percepcije identiteta iz lica najjednostavnije prikazati razmislimo li o osobama s prozopagnozijom - ljudima koji tu sposobnost nemaju, bilo zbog neuralnih lezija, bilo zbog razvojnih poremećaja bez jasnoga neurološkog uzroka. Osobama s prozopagnozijom gotovo je u potpunosti nemoguće percipirati identitet iz lica (Barton, Cherkasova, Press, Intriligator i O'Connor, 2003; Blank, Wieland i von Kriegstein, 2014; Ellis i Florence, 1990) premda nemaju drugih kognitivnih problema ni problema $\mathrm{s}$ percepcijom dobi, spola $\mathrm{i}$ rase. Osobe $\mathrm{s}$ prozopagnozijom često ne uspijevaju prepoznati vlastitu djecu i partnere, a gotovo nikada ne prepoznaju kolege, čak ni kad na istom radnom mjestu rade desetljećima. Zbog toga često pate od depresije i socijalne anksioznosti i teže im je pronaći i zadržati radna mjesta (Dalrymple i sur., 2014; Murray, Hills, Bennets i Bate, 2018). Jasno je, dakle, da je percepcija lica iznimno važna za socijalno funkcioniranje i da poremećaj bilo kojeg koraka u tom procesu dovodi do ozbiljnih socijalnih poteškoća.

Razvojno gledajući, radi se o sposobnosti koja nam je barem do neke mjere urođena, s obzirom na to da novorođenčad stara tek nekoliko minuta više preferira fotografije ljudskih lica od fotografija lica kojima su dijelovi na pogrešnim mjestima (Goren, Sarty i Wu, 1975). Ta se sposobnost tijekom djetinjstva i adolescencije brzo razvija (De Heering, Rossion i Maurer, 2012; Taylor, Batty i Itier, 2004), pa u odrasloj dobi identitete ljudi oko sebe percipiramo sasvim automatski. U 
populacijama je neurotipičnih sudionika istraživanja sposobnost prepoznavanja identiteta izrazito intrinzična - gotovo je nemoguće proces vizualnog procesiranja semantički razložiti na sastavne dijelove jer lica automatski percipiramo u cijelosti. Zbog toga se percepcija lica, za razliku od drugih aspekata vizualnog svijeta oko nas, smatra holističkim procesom (Tanaka i Farah, 1993; Yin, 1969; Young, Hellawell i Hay, 1987). Desetljeća su znanstvenih istraživanja percepcije koja koriste bihevioralne i neuralne metode dovela do modela koji razlučuje tri odvojena, nehijerarhijski organizirana koraka u percepciji lica (Bruce i Young, 1986). Taj općeprihvaćeni model prepoznaje percepciju:

- Lica kao vizualnog podražaja, okarakteriziranu neuralnim EP signalom N170 (Bentin, Allison, Puce, Perez i McCarthy, 1996; Eimer, 2000) i aktivacijom jezgrenih dijelova vizualnog sustava posvećenog percepciji lica koji su locirani u ventralnom zatiljnosljepoočnom (okcipitotemporalnom) režnju, primarno u fuziformnom girusu (Kanwisher, McDermott i Chun, 1997; Pitcher, Walsh i Duchaine, 2011).

- Identiteta lica, okarakteriziranu neuralnim EP signalom N250 (Gosling i Eimer, 2011, Schweinberger, Pickering, Jentzsch, Burton i Kaufmann, 2002; Tanaka, Curran, Porterfield i Collins, 2006) i aktivacijom sekundarnih dijelova vizualnog sustava posvećenog percepciji lica koji su locirani u prekuneusu u parijetalnom režnju i prednjim dijelovima sljepoočnog (temporalnog) režnja (Ishai, Schmidt i Boesiger, 2005; Steeves i sur., 2006; Thomas i sur., 2009).

- Emocija iz lica, okarakteriziranu aktivacijom moždanog tkiva amigdala (Adolphs i sur., 2005).

$\mathrm{U}$ svome radu polazimo od navedenoga modela te razmatramo napretke $\mathrm{u}$ istraživanjima percepcije identiteta i emocija iz lica tijekom posljednjih dvadesetak godina. Bavimo se percepcijom identiteta za koju se u autizmu pretpostavlja da je otežana zbog problema s integracijom informacija, a zatim istražujemo percepciju emocija za koju se u autizmu pretpostavlja da je otežana zbog različitih uzoraka gledanja u lica. Ovdje se posebno osvrćemo na noviju literaturu u kojoj je predstavljena hipoteza aleksitimije, čiji autori smatraju kako se velik dio simptoma u prošlosti pripisivanih autizmu zapravo može objasniti simptomima komorbidne aleksitimije. Na kraju se pregledno dotičemo istraživanja koja koriste metode neurooslikavanja te ističemo važnost različitih uzoraka fiksacije u interpretaciji rezultata neuralne aktivacije navedenih moždanih struktura u autizmu i neurotipičnoj populaciji.

Nakon kritičkog pregleda relevantne literature predlažemo primjene znanstvenih istraživanja na svakodnevni rad s osobama s autizmom, za koje se nadamo da će osobito koristiti stručnjacima u zdravstvenom i socijalnom sustavu te njegovateljima. Kroz čitav rad predlažemo i smjerove budućih istraživanja u poljima eksperimentalne psihologije i kliničke kognitivne neuroznanosti s osobama s 
autizmom u svrhu poboljšanja programa socijalne integracije.

\section{Percepcija identiteta u autizmu}

Sposobnost prepoznavanja identiteta lica neophodna je za uspješno uspostavljanje socijalnog kontakta. Poznato je da osobe s PSA-om imaju smanjenu sposobnost pamćenja i razlikovanja identiteta lica u usporedbi s neurotipičnim osobama, što posebno dolazi do izražaja u zadacima u kojima između stimulusa i testiranja postoji vremenski razmak (Boucher i Lewis, 1992; Wallace, Coleman i Bailey, 2008a).

Za temu su ovog članka najzanimljivije studije koje kvantitativno proučavaju prepoznavanje identiteta usporedbom osoba s PSA-om s neurotipičnim pojedincima. Jasno je da je za određivanje razlika između populacija potrebna standardizacija testova percepcije, za što se najčešće koriste Cambridge Face Memory Test (CFMT, Duchaine i Nakayama, 2006), Cambridge Face Perception Test (CFPT, Duchaine, Germine i Nakayama, 2007) i 20-Item Prosopagnosia Index (PI-20, Shah, Gaule, Sowden, Bird i Cook, 2015). U grupama standardiziranim prema dobi i kvocijentu inteligencije osobe $\mathrm{s}$ autizmom testirane CFMT-om slabije prepoznaju lica od neurotipičnih sudionika (Hedley, Brewer i Young, 2011). Međutim, premda $24 \%$ sudionika istraživanja s PSA-om pokazuje rezultate dvije standardne devijacije ispod prosjeka, mnogi postižu očekivane ili iznadprosječne rezultate za svoju dob, a čak 9 $\%$ postiže odličan rezultat ( $>1$ standardna devijacija iznad prosjeka). Takva je distribucija u skladu s prethodnim studijama koje pokazuju smanjenu sposobnost prepoznavanja lica kod sudionika s PSA-om (Blair, Frith, Smith, Abell i Cipolotti, 2002; Boucher i Lewis, 1992), kao i s drugim istraživanjima koja pokazuju da neke osobe s autizmom postižu rezultat na razini tipičnoj ili iznadprosječnoj za svoju dob (Davies, Bishop, Manstead i Tantam, 1994; Langdell, 1978). Dodatnu sigurnost u navedene testove daje činjenica da regresijske analize ne pokazuju da kvocijent inteligencije ili autistične značajke utječu na prepoznavanje lica, već je jedini značajan prognostički čimbenik uspješnosti pripadnost dijagnostičkoj skupini.

Studije koje se bave pamćenjem lica ovdje definiramo kao one u kojima između prikaza stimulusa i ispitivanja prolazi najmanje 30 sekundi. Jedna je od najvažnijih ispitivanje tijekom kojeg su skupine djece $\mathrm{i}$ adolescenata s autizmom $\mathrm{u}$ dvama zadacima prepoznavale prethodno prikazane stimuluse (Boucher i Lewis, 1992). U prvom su zadatku zaredom pokazana lica, nakon čega se od sudionika istraživanja tražilo da specificiraju jesu li već vidjeli zadano lice. Djeca s poremećajima autističnog spektra postigla su lošiji rezultat od obiju kontrolnih skupina (neurotipične i skupine s poteškoćama u učenju izjednačenima po starosti, spolu i neverbalnoj komunikacijskoj sposobnosti). U drugom su zadatku, uz lica, pokazane i kuće, a rezultati su pokazali da sudionici istraživanja s PSA-om u usporedbi s neurotipičnom populacijom slabije pamte lica, ali ne i kuće. Ovo je prva studija čija disocijacija indicira da je poremećaj u pamćenju osoba s poremećajima autističnog 
spektra donekle specifičan za lica, premda je, naravno, za zaključak da se u PSA-u radi o selektivnom problemu s percepcijom lica potreban opsežniji pregled drugih kategorija stimulusa (npr. automobila, leptira, pasa). Zbog praktičnih limita eksperimentalnog pristupa kognitivnom testiranju pojedinačna se istraživanja najčešće bave samo s nekoliko vizualnih kategorija, iz čega zaključujemo da je vizualna percepcija lica svakako do neke mjere selektivno oštećena u PSA-u, međutim, ne možemo tvrditi da je taj nedostatak isključiv.

U zadacima koji uključuju pamćenje, čak i kad je kognitivna potražnja malena zbog kratkog razmaka između prikaza i testa, redovito se empirijski pokazuje slabija sposobnost percepcije lica osoba s autizmom u odnosu na neurotipične sudionike istraživanja. Pokazala je to studija u kojoj su parovi lica i automobili prikazivani sekvencijski s razmakom od samo 40 milisekundi, a sudionici su morali naznačiti radi li se o parovima istih ili različitih lica i automobila (Wallace i sur., 2008a). Unatoč izrazito kratkom razmaku između prikaza i testiranja osobe s autizmom prepoznavale su dva ista lica kao različita, ali ne i dva automobila. Isti je uzorak pokazan i u zadatku detekcije promjene, u kojem je korišten sekvencijski prikaz lica (u kojima je varirana udaljenost očiju) i kuća (u kojima je varirana udaljenost prozora). Pri ispitivanju lica osobe s autizmom značajno više griješe od neurotipičnih sudionika nego pri ispitivanju kuća (Wallace i sur., 2008a). Danas se zbog takvih se istraživanja u široj znanstvenoj zajednici smatra da je poteškoća u prepoznavanju lica osoba s poremećajima autističnog spektra selektivna te da se percepcija lica u PSA$\mathrm{u}$ vjerojatno oslanja na drugačije kognitivne mehanizme nego u neurotipičnoj populaciji.

\section{Percepcija emocija}

\section{U autizmu}

U polju prepoznavanja lica identitet i emocije sve češće ne smatramo ortogonalnim kategorijama, već istražujemo kognitivne mehanizme koji integriraju podatke u stabilne neuralnokognitivne reprezentacije. Takav pristup primarno motiviraju istraživanja koja pokazuju kako je moguće da se procesiranje identiteta može modulirati emocijama, odnosno da se lica koja prikazuju emocije procesiraju na cjelovitiji način (Gray, Murphy, Marsh i Cook, 2017).

Ipak, općeprihvaćeno je mišljenje da osobe s autizmom imaju poteškoća pri percepciji emocija drugih te izražavanju i razumijevanju vlastitih osjećaja. Dio razloga za to zasiguno leži i u dijagnostičkim kriterijima priručnika DSM-V, koji nemogućnost percepcije neverbalnih izražaja emocija iz lica navode kao jedan od deficita neverbalne komunikacije u autizmu (Američka Psihijatrijska Udruga, 2014). Međutim, stvarna je klinička slika znatno složenija. Studije koje se bave istraživanjima poteškoća u procesiranju emocionalnih izraza lica u autizmu već dugo 
na temelju podataka uspostavljaju različite uzorke koje je donedavno bilo gotovo nemoguće interpretirati. Preostaje nekoliko važnih dilema: jesu li razlike između osoba s autizmom i neurotipičnih populacija dosljedne ili se pojavljuju kao funkcija selektivnih uzoraka ispitanika; mogu li biti objašnjene drugim poteškoćama (npr. dijagnozom aleksitimije) ili su u svojoj osnovici uzrokovane autističnim crtama i, na kraju, jesu li poteškoće ograničene na određene emocije ili su prisutne u čitavom emotivnom spektru? U ovom se pregledu fokusiramo na komorbiditete koji objašnjavaju širok dijapazon simptoma koji su se donedavno smatrali karakteristikama autizma, kao i na metodološka i statistička pitanja o primjerenim načinima uključivanja varijabli u hijerarhijske modele.

Rane su studije pokazivale poteškoće vezane samo uz percepciju određenih emocija kao što su strah (Pelphrey i sur., 2002), tuga (Boraston, Blakemore, Chilvers i Skuse, 2007) i druge negativne emocije (Ashwin, Chapman, Colle i Baron-Cohen, 2006; Humphreys, Minshew, Leonard i Behrmann, 2007; Wallace, Coleman i Bailey, 2008b). Osobe s PSA-om slabije su prepoznavale strah, tugu i gađenje, često miješajući strah i ljutnju, a u prepoznavanju pozitivnih i neutralnih emocija nije bilo razlike $\mathrm{u}$ usporedbi s neurotipičnim skupinama. Zbog toga se pozornost u prvotnim istraživanjima usmjeravala na disocijaciju između pozitivnih i negativnih emocija, a teorije su bile zasnovane na pretpostavci da osobe s PSA-om imaju poteškoća s percepcijom isključivo negativnih emocija. Budući da takav uzorak prepoznavanja pokazuju i osobe s ozbiljnim ozljedama amigdala, pretpostavljalo se da se PSA može objasniti atipičnom ili smanjenom funkcijom amigdala.

Međutim, implikacija hipoteze da osobe s autizmom imaju poteškoća samo s percepcijom negativnih emocija donekle je nelogična. Naime, percepcija pozitivnih emocija u neurotipičnoj je populaciji brža od negativnih (Leppanen i Hietanen, 2004), ali takva se razlika vidi isključivo u percepciji čitavih lica (ne i dijelova lica). Budući da postoje indikacije da osobe s autizmom otežano integriraju tijekom percepcije lica, jednostavna diferencijacija između pozitivnih i negativnih emocija ne objašnjava empirijski uočene razlike.

Zbog te su nelogičnosti druge istraživačke skupine predložile da se razlike u percepciji mogu objasniti diferencijacijom između osnovnih i složenih emocija. Tu teoriju zagovaraju istraživači koji ne nalaze poteškoće kod osoba s autizmom prilikom testiranja osnovnih emocija kao što su radost, tuga, ljutnja i gađenje (Adolphs, Sears i Piven, 2001; Ashwin i sur., 2006). Teorija disocijacije dobiva na snazi time što osobe $\mathrm{s}$ autizmom imaju poteškoća u procesima prepoznavanja složenih izraza lica (npr. pouzdanost, pristupačnost) u usporedbi s neurotipičnim sudionicima (Adolphs i sur., 2001; Boraston, Corden, Miles, Skuse i Blakemore, 2008). Razlike u percepciji jednostavnih i složenih izraza lica između osoba s PSAom i neurotipičnih populacija u navedenim se istraživanjima vide samo u vizualnim modalitetima (npr. iz fotografija), ali ne i u nevizualnim usporedbama (npr. iz leksičkih opisa). 
Ovakav je uzorak rezultata ponovno doveo do pitanja oštećenja amigdala jer su slična istraživanja prethodno provedena u osoba s bilateralnim oštećenjima amigdala (Adolphs, Tranel i Damasio, 1998; Adolphs, Tranel, Damasio i Damasio, 1994, 1995), u kojima se pokazalo lošije prepoznavanje negativnih emocija i pozitivnije prosuđivanje socijalnih situacija, kao i u osoba $\mathrm{s}$ autizmom. Uz to, osobe $\mathrm{s}$ bilateralnim oštećenjima amigdala nemaju teškoća u donošenju socijalnih prosudbi na temelju leksičkih opisa. Zbog sličnih rezultata dviju skupina pretpostavlja se da smanjenoj mogućnosti socijalnog prosuđivanja iz lica doprinosi disfunkcija amigdala. Premda o rezultatima istraživanja koja koriste neuroslikovne metode raspravljamo kasnije u poglavlju „Neuralne razlike u percepciji“, upozoravamo na malen broj sudionika u većini navedenih studija i potrebi za daljnjim testiranjem ove hipoteze u većim skupinama sudionika.

Dakle, znanstveno se razumijevanje toga kako osobe s autizmom percipiraju emocionalne izraze lica u posljednjih nekoliko godina uvelike promijenilo. Zbog varijabilnosti problema s percepcijom emocija u uzorcima osoba s PSA-om, prvotni su modeli pretpostavljali da poteškoće u semantičkoj percepciji neizbježno proizlaze iz poteškoća vezanih uz specifičnu kategoriju emocija - bilo negativnih ili složenih. Budući da ta objašnjenja nisu uspijevala objasniti varijabilnost uzoraka unutar populacije osoba s autizmom, složeniji modeli kognitivnih mehanizama emotivne percepcije u autizmu pretpostavljaju da općeniti problemi s integracijom podataka (Happe i Frith, 2006) dovode do poteškoća u integraciji signala iz različitih dijelova lica (Boraston i sur., 2008; Shah, Bird i Cook, 2016). Usporena integracija ili nemogućnost uspostavljanja integracije vjerojatno dovode do poteškoća podjednako u zadacima u laboratorijskim uvjetima (koji zahtijevaju semantičko prepoznavanje emocija), kao i u svakodnevnom životu (koji zahtijeva primjerene i brze reakcije na emocije).

Upravo zbog potrebe za brzom i primjerenom reakcijom na emocije u stvarnom životu, pretpostavlja se i da vremenska dinamika igra značajnu ulogu u procesu integracije signala. Zato aktualna istraživanja pokušavaju protumačiti načine na koje podatke koje percipiramo iz lica integriramo u semantičko prepoznavanje emocionalne kategorije. Zbog toga se istraživačke grupe intenzivno bave vremenskim vidom razumijevanja emotivnih izraza lica te ispitivanjima dijela tog procesa, koji je u autizmu otežan.

\section{Poteškoće povezane samo s regijom očiju}

Obično se smatra da osobe s autizmom imaju poteškoća s gledanjem u očnu regiju (Boraston i sur., 2008; Dalton i sur., 2005; Pelphrey i sur., 2002; Rutherford, Clements i Sekuler, 2007) zbog atipičnih uzoraka gledanja lica potvrđenih studijama koje koriste metodu praćenja pogleda. Istraživači smatraju da se osobe s autizmom dispropocionalno fokusiraju na regiju usta (Joseph i Tanaka, 2003). Premda nije sasvim jasno koji kognitivni mehanizam potiče izbjegavanje regije očiju (Cuve, Gao 
i Fuse, 2018), jedna od teorija koja objašnjava razlike u procesiranju lica u osoba s autizmom jest da hiperaktivacija središnjeg emotivnog kruga stvara pojačanu osjetljivost na socijalne podražaje te da je efikasno kompenzirati smanjenom fiksacijom pogleda.

I u uzorcima djece s autizmom vidimo smanjeno fiksiranje na očnu regiju i povećano posvećivanje pozornosti regiji usta (Langdell, 1978). Djeca s autizmom značajno bolje prepoznaju identitet na temelju područja usta u usporedbi sa neurotipičnim vršnjacima, što indicira da možda pridaju različitu važnost podacima iz dijelova lica ili da već u ranijoj dobi izbjegavaju fokus na oči kao kompenzaciju za hiperaktivacijski uzorak pri gledanju socijalnih podražaja. Relevantna istraživanja pokazuju kako djeca s autizmom, za razliku od neurotipične djece, kojima kontekst ostatka lica koristi u prepoznavanju identita, benefit od konteksta deriviraju samo kad im je zadatak prepoznati identitet na temelju usta, ali ne i očiju (Tanaka i Farah, 1993; Young i sur., 1987). Ovi rezultati upućuju na to da je, zbog izbjegavanja regije očiju, cjelovito (holističko) procesiranje lica na neki način poremećeno. Ova su istraživanja pogotovo važna za istraživače koji koriste metode neurooslikavanja jer su rezultati studija koje koriste te metode posebno osjetljivi na smanjenu fiksaciju pogleda na određene dijelove lica (vidi „Neuralne razlike u percepciji“).

\section{U aleksitimiji}

Jedna od najnovijih teorija koje mogu objasniti varijabilnost rezultata različitih studija percepcije emocija iz lica u autizmu poznata je kao aleksitimijska hipoteza (Cook, Brewer, Shah i Bird, 2013), koja zagovara ideju da se razlike između osoba s PSA-om i neurotipične populacije uvelike mogu objasniti efektima aleksitimije. Aleksitimija, supklinička dijagnoza povezana s nemogućnošću interpretacije svojih i tuđih emocija, prepoznavanjem vlastitih emocija i fizičkih stanja i poteškoćama s upotrebom jezika koji opisuje emocije i fizička stanja, nedavno je postala središnjom temom istraživanja osoba s autizmom. Sustavne studije pokazuju da je u općoj populaciji incidencija aleksitimije $10 \%$, dok u populacijama s autizmom incidencija aleksitimije često prelazi $50 \%$ (Berthoz i Hill, 2005; Hill, Berthoz i Frith, 2004; Lombardo, Barnes, Wheelwright i Baron-Cohen, 2007). Osobama s aleksitimijom otežana je procjena vlastitih emocija (Nemiah, Freyberger i Sifneos, 1976) kao i prepoznavanje tuđih emocija iz lica (Cook i sur., 2013; Parker, Prkachin i Prkachin, 2005; Prkachin, Casey i Prkachin, 2009). Aleksitimija se, s obzirom na supkliničku narav poteškoće, dijagnosticira korištenjem serije ljestvica samoprocjene, najčešće Toronto Alexythimia Scale (TAS-20, Taylor, Ryan i Bagby, 1985). Premda se, dakako, može postaviti pitanje validnosti korištenja ljestvica samoprocjene u populacijama koje imaju poteškoća s percepcijom vlastitih stanja, TAS-20 validiran je podjednako u populacijama koje imaju i nemaju problema s percepcijom emocija, zbog čega se smatra pouzdanom i valjanom mjerom (Parker, Taylor i Bagby, 2001; Speranza, Loas, Wallier i Corcos, 2007; Taylor, Bagby, Ryan i Parker, 1990). Općenito se smatra da je aleksitimija posljedica razvojne disfunkcije koja rezultira 
smanjenom kortikalnom povezanosti između limbičkih struktura (amigdale, insula) važnih za percepciju i raspoznavanje osjećaja (Bird i sur., 2010; FeldmanHall, Dalgleish i Mobbs, 2013). Uz razlike u kortikalnoj povezanosti neke studije upućuju i na redukciju u volumenu sive tvari u područjima mozga relevantnima za emocionalno procesiranje između populacija s visokom i niskom aleksitimijom (Ihme i sur., 2013).

Dakako, fokus je u ovom pregledu na poteškoće u percepciji lica i emocija, simptoma aleksitimije koji su se tradicionalno pripisivali autizmu. S obzirom na prevalentnost autizma u društvu i važnost integracije osoba s PSA-om u obrazovne i socijalne strukture, od osobite je znanstvene i društvene važnosti da eksperimenti kojima je cilj bolje razumijevanje simptoma autizma budu pažljivo metodološki dizajnirani i provedeni kako bi omogućili razlučivanje utjecaja autizma od utjecaja prateće (klinički komorbidne) aleksitimije.

Važnost aleksitimije kao nezavisne varijable u modelima autizma postala je jasna kad se pokazalo da pojedinci visoko procijenjeni na spektru aleksitimije pokazuju manje nelagode u situacijama u kojima im je pokazana druga osoba koju nešto boli (Bird i Cook, 2013; FeldmanHall i sur., 2013), što je dovelo do detaljnijeg ispitivanja empatijskog ponašanja u toj populaciji. Sličan je rezultat proizašao i iz neuralnih metoda istraživanja - kod pojedinaca koji su imali poteškoća u prepoznavanju emocionalnih teškoća drugih ljudi utvrđena je smanjena neuralna aktivacija prednje insule i temporo-parijetalnog spoja, dviju regija koje smatramo ključnima u percepciji uznemirenosti drugih ljudi (Bird i sur., 2010; FeldmanHall i sur., 2013). To je dovelo do zaključka kako se u osoba s aleksitimijom zacijelo radi o poteškoći u procesiranju svih negativnih emocija.

Međutim, daljnja su testiranja pokazala da je mehanizam poremećaja ipak nešto složeniji. Naime, kada su sudionicima pokazani neutralni i negativni izrazi lica, uz variranje brzine prezentacije, rezultati su pokazali zanimljiv obrazac (Parker i sur., 2005; Prkachin i sur., 2009). Očekivalo se, naravno, da brzina prezentacije neće biti statistički značajan faktor u mjerenju poteškoća kod osoba s aleksitimijom, međutim, sudionici su pokazali poteškoće pri prepoznavanju negativnih emocija samo pri brzoj prezentaciji, ali ne i pri sporoj. Budući da je korištena osjetljiva paradigma, istraživači su zaključili kako se radi o poteškoći u rapidnom procesiranju negativnih emocija u uvjetima u kojima se u lice ne može gledati neograničeno dugo, sličnima situacijama u stvarnome životu. Ipak, treba naglasiti dva ograničenja ovog istraživanja - to što sudionici nisu morali semantički definirati emociju koju su percipirali (nego samo da su primijetili emociju) te da u eksperiment nisu bile uključene pozitivne emocije (pa nije jasno je li poteškoća u procesiranju vremenske prirode, ali ograničena na negativne emocije ili utječe na percepciju čitavoga emotivnog spektra). Kako bi se odgovorilo na ta pitanja, sličan bi eksperiment trebalo replicirati koristeći metode detekcije signala koje omogućavaju konstrukciju psihometrijske funkcije. Konkretno, valjalo bi ispitati jesu li psihometrijske funkcije detekcije signala različite za negativne i pozitivne emocije u uvjetima brzog i sporog 
prikazivanja lica u tim dvjema populacijama. Time bi se jasno disocirao utjecaj brzine prezentacije (brza, spora) od utjecaja tipa emocije (pozitivna, negativna, bez emocija) i utjecaja populacije (aleksitimija, kontrola). Naime, moguće je da integrativni sustav osoba s aleksitimijom nije nepostojeć, već samo donekle usporen.

U dobro kontroliranim populacijama osoba s autizmom i komorbidnom aleksitimijom, osoba s autizmom bez komorbidne aleksitimije i neurotipičnim sudionicima pronađene su razlike u sposobnosti prepoznavanja emocija, ali ne i identiteta (Cook i sur., 2013). Posebno je važna dvostruka disocijacija rezultata koja pokazuje kako simptomi aleksitimije statistički objašnjavaju individualnu varijabilnost $\mathrm{u}$ preciznosti procjene emocionalnih stanja, dok težina dijagnoze autizma nije statistički značajan faktor. Uz to, takve disocijacije nema u regresivnom modelu testiranja percepcije identiteta - točnost na tom zadatku statistički se ne može objasniti ni aleksitimijom ni autizmom. To je istraživanje među prvima pokazalo iznimnu važnost kontrolne varijable aleksitimije, kojoj se do tada nije pripisivala indikativna uloga u istraživanjima autizma.

Daljnje su studije pokazale slične uzorke u istraživanjima mehanizama koji omogućuju prepoznavanje karakternih osobina i emocija. Osobe s aleksitimijom i bez nje na sličan način asociraju emocije s karakternim osobinama (Brewer, Happé, Cook i Bird 2015). Međutim, razlaganje testiranih karakternih osobina na one koje se mogu prosuditi na temelju strukturalnih značajki (npr. simetrije dviju polovica lica) i one koje se mogu prosuditi samo na temelju emocija pokazuje da je varijabilnost odgovora osoba s aleksitimijom veća pri procjenama pouzdanosti i agresivnosti neke osobe, dok u procjenama privlačnosti nema razlike u usporedbi $\mathrm{s}$ kontrolnim uzorkom. Pretpostavlja se zato da se osobe s autizmom disproporcionalno oslanjaju na mehanizme koji koriste strukturalne, a ne emocionalne značajke lica. Budući da se smatra kako socijalna interakcija i integracija u socijalnu grupu pretpostavlja precizno stvaranje procjena o karakternim osobinama, moguće je da je jedan od razloga zbog kojih se osobe s autizmom često povlače iz socijalnih situacija upravo aleksitimija, koja onemogućava točno prepoznavanje važnih signala iz emocionalnih izraza lica.

Starija literatura osobe $\mathrm{s}$ autizmom i aleksitimijom i osobe $\mathrm{s}$ autizmom bez aleksitimije tretira kao jedinstvenu populaciju. Zbog toga se često ne koriste statističke analize koje omogućuju detekciju stvarnih razlika između tih dviju subpopulacija i neurotipične populacije s kojom ih uspoređuju. Vjerojatno je, dakle, da uzorci iz tih subpopulacija nemaju dovoljnu statističku snagu za detektiranje stvarnih razlika između populacija. Dodatno je problematično to što kriteriji koji se najčešće koriste za uključivanje u kontrolnu skupinu ne uključuju testiranje ni aleksitimije ni drugih komorbiditeta (recimo, značajki nekih mentalnih bolesti). Nedavno se utvrđeno kako između četvrtine i trećine sudionika u tipičnim kontrolnim skupinama, unatoč nedostatku kliničke dijagnoze, pokazuje srednje ozbiljne ili ozbiljne indikacije za značajke anksioznosti ili depresije (Ichijo i sur., 2019). S obzirom na visoki komorbiditet aleksitimije i depresije/anksioznosti, faktor 
aleksitimije vjerojatno je zanemaren i u neurotipičnoj populaciji, a ne samo u populaciji osoba s PSA-om.

Zaključujemo, dakle, kako se iz daljnjih istraživanja grupnih razlika između osoba s autizmom i neurotipičnih populacija ne smije isključiti nezavisna varijabla aleksitimije, koja često prati dijagnozu autizma. Kao rezultat prepoznate disocijacije između dviju dijagnoza, očekujemo i da će u sljedećim izdanjima dijagnostičkih priručnika simptomatika problema u percepciji emocija i identiteta iz lica biti isključena iz lista simptoma autizma, pogotovo zato što su drugi simptomi u istoj kategoriji osjetljiviji indikatori dijagnoze autizma i nisu podložni varijaciji aleksitimijom.

S praktičnog je stajališta važno istaknuti kako usprkos visokoj incidenciji komorbiditeta između autizma i aleksitimije, barem $50 \%$ osoba s autizmom nema aleksitimiju. Očekivano, klinička slika takvih osoba na psihološkim testiranjima osjetno varira od kliničke slike osoba s autizmom i komorbidnom aleksitimijom. Teoretski je, dakle, moguće da se, s obzirom na opću heterogeneičnost dijagnoze PSA, dijagnoza osporava osobama koje ne pokazuju dostatan broj poteškoća u neverbalnoj komunikaciji. Međutim, kao što se pokazalo, takav bi uzorak simptoma mogao indicirati pacijenta koji jednostavno nema probleme povezane $\mathrm{s}$ aleksitimijom. Budući da u državama diljem svijeta razna zakonska prava i prilagodbe obrazovnog sustava ovise o postojanju formalne dijagnoze, istraživanja koja neprecizno definiraju populacije kojima se bave mogu nehotice nepovoljno utjecati na javne politike koje reguliraju sredstva osigurana osobama s autizmom. Stoga je iznimno važno da znanstvena istraživanja uključe obje varijable u svoje analize te da se dijagnostički kriteriji na temelju znanstvenih spoznaja što konkretnije moguće prilagode stvarnim dijagnozama osjetljivima na prisutnost čestih komorbiditeta.

\section{Neuralne razlike u percepciji: Istraživanja koja koriste metode neurooslikavanja}

Jedno od najvažnijih pitanja u sferi neuroznanosti jest na koji način razlike između populacija u kognitivnim studijama odgovaraju razlikama u uzorcima neuralnih aktivacija. Pri proučavanju procesiranja lica i poremećaja procesiranja lica posebna se pozornost pridaje fuziformnom girusu (FFA), okcipitalnom girusu (OFA) i amigdalama, jezgrenim neuralnim regijama uključenima u osnovno procesiranje lica (Kanwisher i sur., 1997; Pitcher i sur., 2011). Pretpostavlja se da su navedeni dijelovi mozga sastavni dijelovi vizualnog korteksa za percepciju lica te da neuralni mehanizam posvećen isključivo procesiranju lica postoji upravo zbog njihove evolucijske važnosti (za pregled vidi Kanwisher i Yovel, 2006).

Treba, međutim, spomenuti da je hipoteza o specijaliziranosti tih regija za procesiranje lica i dalje predmet rasprave. Dio znanstvenika koji se bavi tim pitanjem smatra da je njihova aktivacija rezultat procesiranja svih predmeta čije raspoznavanje 
zahtijeva visoku ekspertizu te da su ljudi zbog stalne izloženosti licima specijalizirani za njihovo raspoznavanje (Gauthier, Tarr, Anderson, Skudlarski i Gore, 1999; Tarr i Gauthier, 2000). Takvu hipotezu uvelike podupiru studije koje pokazuju da eksperti za neku vizualnu kategoriju (npr. ljudi koji se bave uzgojem pasa ili automobilskim utrkama) pokazuju uzorke neuralne aktivacije u fuziformnom i okcipitalnom girusu za tu kategoriju nalik uzorcima neurotipične populacije za lica (Tarr i Gauthier, 2000). Premda je pregled istraživanja koja nastoje razlučiti između tih dviju hipoteza izvan opsega ovog članka, zanimljivo ih je razmotriti u svjetlu toga da osobe s autizmom izbjegavaju situacije u kojima ljude moraju gledati neposredno u lice. Možda upravo zbog toga karakterističnog uzorka ponašanja tijekom odrastanja ne dolazi do neuralne diferencijacije kortikalnih regija, odnosno osobe s autizmom ne postaju eksperti za lica tijekom kritičnih razvojnih razdoblja. Dodatno je zanimljivo pitanje specijalizacije, jer osobe s autizmom često imaju vrlo usku ekspertizu za određenu kategoriju. Hipoteza o ekspertnosti pretpostavlja da bi neuralna aktivacija osoba s autizmom tijekom percepcije kategorija koje preferiraju trebala biti slična uzorcima neurotipične populacije prilikom percepcije lica.

\section{Fuziformni girus}

U studijama koje koriste funkcionalnu magnetsku rezonancu (fMRI) velik je broj istraživanja (Critchley i sur., 2000; Dalton i sur., 2005; Grelotti i sur., 2005; Pierce, Muller, Ambrose, Allen i Courchesne, 2001) prilikom procesiranja lica uputio na smanjenu ili atipičnu aktivaciju fuziformog girusa u osoba s autizmom. Kao mogući uzroci takvih rezultata navode se nepostojeći, neaktivan ili strukturalno promijenjen girus.

Smatra se da je hipoaktivacija fuziformnog girusa u autizmu možda popratna pojava uzoraka gledanja (Dalton i sur., 2005; Pierce, Haist, Sedaghat i Courchesne, 2004). Aktivacija fuziformnog girusa povezuje se s temporalnom fiksacijom na očnu regiju, zbog čega se pretpostavlja da se hipoaktivacija u autizmu može objasniti skraćenom fiksacijom. Hipoaktivacija je možda, dakle, posljedica specifično različitog uzorka gledanja u autizmu za koji smatramo da proizlazi iz hiperaktivacije centralnoga neuralnog kruga za emocije, koja, pak, dovodi do pojačane osjetljivosti na socijalne podražaje.

Premda se svojedobno smatralo da je aktivacija fuziformnog girusa rezultat holističke percepcije lica, studije su otada pokazale da i sama prezentacija očne regije može rezultirati aktivacijom slične magnitude (McCarthy, Puce, Belger i Allison, 1999). Zbog toga ne iznenađuje što se prilikom prikazivanja lica osobama s autizmom često uočava smanjena aktivacija fuziformnog girusa te da već statističko uključenje varijable uzorka gledanja tu razliku između populacija smanjuje ili eliminira. 


\section{Amigdala}

Istraživanja aktivacije amigdala prilikom procesiranja lica u osoba s autizmom pobudila su veliki interes zbog medijske popraćenosti ranih studija na temelju kojih se teoretiziralo da se smanjena reaktivnost amigdala na emotivne stimuluse može objasniti nedostatkom empatije u osoba s autizmom (Baron-Cohen i sur., 2000; Schultz, 2005) s obzirom na to da su neuralna istraživanja pokazivala hipoaktivaciju amigdale prilikom gledanja lica koja prikazuju emocije (Critchley i sur., 2000; Pierce i sur., 2001). Međutim, kasnija su istraživanja upozorila na suptilnije efekte - neke studije nalaze osjetno manje magnitude hipoaktivacije (Wang, Dapretto, Hariri, Sigman i Bookheimer, 2004), dok druge pokazuju hipoaktivaciju za emocionalna lica, ali značajnu aktivaciju za stimuluse s emotivnim značajkama bez socijalnih komponenti (Grelotti i sur., 2005).

Možda se, dakle, empatijski deficiti osoba s autizmom mogu objasniti interoceptivnim poteškoćama povezanima s aleksitimijom? Istraživanja fMRI-em zato su tražila uzorke aktivacije limbičkog sustava povezane s empatičnim procesiranjem stvarnih situacija u društvenim okruženjima u populacijama $\mathrm{s}$ autizmom i aleksitimijom (Bird i sur., 2010). Očekivano, u situacijama koje su izazivale empatiju aktivacija je bila povećana u lijevoj prednjoj insuli i bilateralno u amigdalama. Međutim, u čitavoj se populaciji magnitudu neuralnog signala moglo predvidjeti stupnjem aleksitimije (magnituda neuralnog signala u amigdalama obrnuto je proporcionalna stupnju aleksitimije). Ključno je da, kad se u obzir uzme stupanj aleksitimije, nema razlike u empatijskom neuralnom odgovoru između neurotipične populacije i populacije s autizmom. Razlike u empatiji koje su se desetljećima u znanstvenoj zajednici prikazivale kao karakteristično obilježje autizma vjerojatno se, dakle, pojavljuju zbog visokog komorbiditeta s aleksitimijom, a ne kao nužna posljedica socijalnih poteškoća u autizmu.

Na kraju, Dalton i sur. (2005) nalaze povećanu aktivaciju amigdala u autizmu koristeći statističku metodu osjetljivu na razlike u fiksacijskim uzorcima. Naime, ova studija po prvi put uključuje fiksaciju pogleda u statistički model, čime se postiže osjetljivost na spomenute individualne razlike u uzorcima gledanja. Tijekom fiksacije, regije amigdala u osoba s autizmom bile su povećano aktivne, odnosno pokazale su pojačan emocionalni neuralni odgovor. Pretpostavljamo da je moguće da smanjena fiksacija možda olakšava smanjivanje pretjeranoga fiziološkog uzbuđenja u situacijama koje uključuju socijalne podražaje.

\section{Zaključak o neuralnim metodama}

$\mathrm{Na}$ temelju navedenih studija jasna je iznimna važnost odabira prikladne statističke metode $u$ istraživanjima osoba s autizmom i/ili aleksitimijom. Istraživanja koje ne uzimaju u obzir različite uzorke fiksacije povećavaju mogućnost pogreške prve vrste (odbacivanja nulte i prihvaćanja alternativne hipoteze). To može dovesti 
do pogrešnog zaključka da je statistički značajna razlika u neuralnoj aktivaciji funkcija populacijske razlike, a ne efekt moduliran uzorcima gledanja, odnosno fiksacije. Zato upozoravamo na važnost uključivanja uzorka fiksacije u statističke modele kao nezavisne varijable u multivarijabilnim regresijama (generalnim lineranim modelima).

Uz to, nedavna istraživanja jasno pokazuju i to da je važnost aleksitimije koja prati autizam u literaturi dugo zanemarivana. Budući da se značajke aleksitimije i autizma mjere kontinuiranim, a ne diskretnim varijablama, nekoliko je mogućih rješenja za statističko uzimanje u obzir njihova međusobnog komorbiditeta. Jedna je mogućnost podijeliti uzorak prilikom testiranja populacije s autizmom na osobe $\mathrm{s}$ niskom i visokom aleksitimijom (u odnosu na medijan), ali s obzirom na učestalu incidenciju aleksitimije u autizmu, takva metoda često rezultira previsokim medijanom, a nastale grupe gube relevantnost. Alternativno se $u$ istraživanjima individualnih razlika u modele multivarijabilnih regresija može uključiti brojčani rezultat testiranja aleksitimije. Ipak, za istraživanja koja se bave ispitivanjem poveznica između osoba $\mathrm{s}$ autizmom i neurotipičnih populacija, preporuča se prikupiti diskretne grupe sudionika s autizmom i aleksitimijom, s autizmom, a bez aleksitimije te bez autizma i aleksitimije. Tada se grupnom usporedbom može utvrditi utječe li pripadnost populaciji na varijable od interesa.

\section{Zaključak}

Istraživanja percepcije socijalnih stimulusa iz lica znatno su napredovala posljednjih nekoliko desetljeća kao rezultat dorade metodoloških pristupa i dizajna studija vizualne percepcije, poboljšane preciznosti neuralnih metoda te preciznijega razlučivanja različitih dijagnostičkih skupina. I u medicini i u znanosti poboljšanje dijagnostičkih kriterija kojima se razdvajaju komorbidne dijagnoze dovodi do raspoznavanja disocijativnih razlika u uzorcima ponašanja i u neuralnoj aktivaciji osoba s autizmom, osoba s autizmom i aleksitimijom te osoba s aleksitimijom bez autizma.

Uz napredak u preciznosti istraživačkih metoda napredovalo je i znanstveno razumijevanje statističkih faktora koji igraju kritičnu ulogu u istraživanjima kliničkih i supkliničkih poremećaja u vizualnoj percepciji. Budući da istraživanja koji se bave perceptivnim mehanizmima u posebnim populacijama često utječu na razvoj javnih politika integracije u obrazovne i socijalne programe, važno je da se ona obavljaju s posebnom metodološkom i statističkom pozornošću. Zbog toga upućujemo na tradicionalno zanemarene varijable - specifično aleksitimijske značajke u kognitivnim (bihevioralnim) istraživanjima te uzorak gledanja u neuralnim istraživanjima.

Percepcija identiteta u autizmu možda je otežana zato što ta osnovna socijalna sposobnost zahtijeva holističku percepciju, odnosno integraciju podataka tijekom 
paralelnog procesiranja. Budući da su integrativni procesi u autizmu otežani ili usporeni, proces normalne percepcije identiteta često je nemoguć i u svakodnevnim socijalnim situacijama i u laboratorijskim uvjetima. Pretpostavlja se da je sličan razlog temelj poteškoća s percepcijom emocija u autizmu, odnosno da nemogućnost integracije podataka iz očne regije i podataka iz ostatka lica onesposobljava tipičnu percepciju emocija. Međutim, nedavna istraživanja pokazuju kako se značajan udio varijance u percepciji emocija u autizmu može objasniti aleksitimijskim značajkama, odnosno da je vjerojatnije kako poteškoće u emotivnoj percepciji proizlaze iz komorbidne dijagnoze aleksitimije, a ne kao rezultat poremećaja autističnog spektra.

Do sličnih je metodoloških pomaka došlo i u neuralnim istraživanjima u kojima se značajne razlike između aktivacije fuziformnog girusa i amigdala prilikom percepcije lica te emocija iz lica mogu objasniti uzorcima gledanja. Naime, područje očiju često je izrazito informativno u percepciji lica, ali u osoba s autizmom izaziva hiperaktivaciju središnjeg neuralnog kruga. Zbog toga često izbjegavaju gledati u područje očiju, pa varijabla različitih uzoraka gledanja objašnjava značajnu varijancu uzoraka neuralne aktivacije. S obzirom na nedostatak temporalne (funkcionalna magnetska rezonanca) i spacijalne (elektroencefalografija, transkranijalna magnetska stimulacija) preciznosti suvremenih neuralnih metoda pri analizi podataka o neuralnoj aktivaciji preporuča se uzeti u obzir uzorke gledanja kako bi se izbjegle statističke pogreške prve vrste.

$\mathrm{Na}$ temelju iznesenoga vidimo da je $\mathrm{u}$ istraživanjima neuralnih i kognitivnih mehanizama autizma došlo do potpunoga premještanja žarišta istraživačkog interesa na studije individualnih razlika umjesto studija populacijskih uzoraka. Taj trend uzima u obzir komorbiditete te istraživačima omogućuje testiranje hipoteza lišenih pretpostavki o populacijskoj distribuciji, čime se izbjegava korištenje neprimjerenih statističkih metoda i modela koje pretpostavljaju normalno distribuirane značajke. S obzirom na to da studije individualnih razlika upravo zbog toga često zahtijevaju znatno veće resurse te regrutiranje većeg broja sudionika istraživanja, kao i široku dostupnost potencijalnih kandidata za sudjelovanje, one su često teže izvedive u malim istraživačkim zajednicama. Dugotrajne suradnje stručnjaka s nekoliko istraživačkih lokacija dugoročno su vjerojatno najbolje rješenje za istraživače autističnoga spektra jer će takve suradnje omogućiti dovoljno velike i reprezentativne uzorke za opsežne i potpune analize bihevioralnih i neuralnih uzoraka u toj populaciji.

\section{Literatura}

Adolphs, R., Gosselin, F., Buchanan, T. W., Tranel, D., Schyns, P. i Damasio, A. R. (2005). A mechanism for impaired fear recognition after amygdala damage. Nature, 433(7021), 68-72. 
Adolphs, R., Sears, L. i Piven, J. (2001). Abnormal processing of social information from faces in autism. Journal of Cognitive Neuroscience, 13(2), 232-240.

Adolphs, R., Tranel, D. i Damasio, A. R. (1998). The human amygdala in social judgment. Nature, 393(6684), 470-474.

Adolphs, R., Tranel, D., Damasio, H. i Damasio, A. R. (1994). Impaired recognition of emotion in facial expressions following bilateral damage to the human amygdala. Nature, 372(6507), 669-672.

Adolphs, R., Tranel, D., Damasio, H. i Damasio, A. R. (1995). Fear and the human amygdala. Journal of Neuroscience, 15(9), 5879-5891.

Američka Psihijatrijska Udruga. (2014). DSM-5 Dijagnostički i statistički priručnik za duševne poremé́aje. Jastrebarko: Naklada Slap.

Ashwin, C., Chapman, E., Colle, L. i Baron-Cohen, S. (2006). Impaired recognition of negative basic emotions in autism: A test of the amygdala theory. Social Neuroscience, 1(3-4), 349-363.

Ballew, C. C. i Todorov, A. (2007). Predicting political elections from rapid and unreflective face judgments. Proceedings of the National Academy of Sciences, 104(46), 1794817953.

Baron-Cohen, S., Ring, H. A., Bullmore, E. T., Wheelwright, S., Ashwin, C. i Williams, S. C. R. (2000). The amygdala theory of autism. Neuroscience and Biobehavioral Reviews, 24(3), 355-364.

Barton, J. J., Cherkasova, M. V., Press, D. Z., Intriligator, J. M. i O’Connor, M. (2003). Developmental prosopagnosia: A study of three patients. Brain and Cognition, 51(1), 12-30.

Bentin, S., Allison, T., Puce, A., Perez, E. i McCarthy, G. (1996). Electrophysiological studies of face perception in humans. Journal of Cognitive Neuroscience, 8(6), 551-565.

Berthoz, S. i Hill, E. L. (2005). The validity of using self-reports to assess emotion regulation abilities in adults with autism spectrum disorder. European Psychiatry, 20(3), 291-298.

Bird, G. i Cook, R. (2013). Mixed emotions: The contribution of alexithymia to the emotional symptoms of autism. Translational Psychiatry, 3(7), e285.

Bird, G., Silani, G., Brindley, R., White, S., Frith, U. i Singer, T. (2010). Empathic brain responses in insula are modulated by levels of alexithymia but not autism. Brain, 133(5), 1515-1525.

Blair, R. J. R., Frith, U., Smith, N., Abell, F. i Cipolotti, L. (2002). Fractionation of visual memory: Agency detection and its impairment in autism. Neuropsychologia, 40(1), 108118.

Blank, H., Wieland, N. i von Kriegstein, K. (2014). Person recognition and the brain: Merging evidence from patients and healthy individuals. Neuroscience and Biobehavioral Reviews, 47, 717-734. 
Boraston, Z., Blakemore, S. J., Chilvers, R. i Skuse, D. (2007). Impaired sadness recognition is linked to social interaction deficit in autism. Neuropsychologia, 45(7), 1501-1510.

Boraston, Z. L., Corden, B., Miles, L. K., Skuse, D. H. i Blakemore, S. J. (2008). Brief report: Perception of genuine and posed smiles by individuals with autism. Journal of Autism and Developmental Disorders, 38(3), 574-580.

Boucher, J. i Lewis, V. (1992). Unfamiliar face recognition in relatively able autistic children. Journal of Child Psychology and Psychiatry, 33(5), 843-859.

Brewer, R., Happé, F., Cook, R. i Bird, G. (2015). Commentary on "Autism, oxytocin and interoception": Alexithymia, not Autism Spectrum Disorders, is the consequence of interoceptive failure. Neuroscience and Biobehavioral Reviews, 56, 348-353.

Bruce, V.i Young, A. (1986). Understanding face recognition. British Journal of Psychology, 77(3), 305-327.

Cook, R., Brewer, R., Shah, P. i Bird, G. (2013). Alexithymia, not autism, predicts poor recognition of emotional facial expressions. Psychological Science, 24(5), 723-732.

Critchley, H. D., Daly, E. M., Bullmore, E. T., Williams, S. C., Van Amelsvoort, T., Robertson, D. M. i Murphy, D. G. (2000). The functional neuroanatomy of social behaviour: Changes in cerebral blood flow when people with autistic disorder process facial expressions. Brain, 123(11), 2203-2212.

Cuve, H. C., Gao, Y. i Fuse, A. (2018). Is it avoidance or hypoarousal? A systematic review of emotion recognition, eye-tracking, and psychophysiological studies in young adults with autism spectrum conditions. Research in Autism Spectrum Disorders, 55, 1-13.

Dalrymple, K. A., Fletcher, K., Corrow, S., das Nair, R., Barton, J. J., Yonas, A. i Duchaine, B. (2014). "A room full of strangers every day": The psychosocial impact of developmental prosopagnosia on children and their families. Journal of Psychosomatic Research, 77(2), 144-150.

Dalton, K. M., Nacewicz, B. M., Johnstone, T., Schaefer, H. S., Gernsbacher, M. A., Goldsmith, H. H. i Davidson, R. J. (2005). Gaze fixation and the neural circuitry of face processing in autism. Nature Neuroscience, 8(4), 519-526.

Davies, S., Bishop, D., Manstead, A. S. i Tantam, D. (1994). Face perception in children with autism and Asperger's syndrome. Journal of Child Psychology and Psychiatry, 35(6), 1033-1057.

De Heering, A., Rossion, B. i Maurer, D. (2012). Developmental changes in face recognition during childhood: Evidence from upright and inverted faces. Cognitive Development, 27(1), 17-27.

Duchaine, B. i Nakayama, K. (2006). The Cambridge Face Memory Test: Results for neurologically intact individuals and an investigation of its validity using inverted face stimuli and prosopagnosic participants. Neuropsychologia, 44(4), 576-585.

Duchaine, B., Germine, L. i Nakayama, K. (2007). Family resemblance: Ten family members with prosopagnosia and within-class object agnosia. Cognitive Neuropsychology, 24(4), 419-430. 
Eimer, M. (2000). The face-specific N170 component reflects late stages in the structural encoding of faces. Neuroreport, 11(10), 2319-2324.

Ellis, H. D. i Florence, M. (1990). Bodamer's (1947) paper on prosopagnosia. Cognitive Neuropsychology, 7(2), 81-105.

FeldmanHall, O., Dalgleish, T. i Mobbs, D. (2013). Alexithymia decreases altruism in real social decisions. Cortex, 49(3), 899-904.

Gauthier, I., Tarr, M. J., Anderson, A. W., Skudlarski, P. i Gore, J. C. (1999). Activation of the middle fusiform'face area'increases with expertise in recognizing novel objects. Nature Neuroscience, 2(6), 568-573.

Goren, C. C., Sarty, M. i Wu, P. Y. (1975). Visual following and pattern discrimination of face-like stimuli by newborn infants. Pediatrics, 56(4), 544-549.

Gosling, A. i Eimer, M. (2011). An event-related brain potential study of explicit face recognition. Neuropsychologia, 49(9), 2736-2745.

Gray, K. L., Murphy, J., Marsh, J. E. i Cook, R. (2017). Modulation of the composite face effect by unintended emotion cues. Royal Society Open Science, 4(4), 160867.

Grelotti, D. J., Klin, A. J., Gauthier, I., Skudlarski, P., Cohen, D. J., Gore, J. C. i Schultz, R. T. (2005). fMRI activation of the fusiform gyrus and amygdala to cartoon characters but not to faces in a boy with autism. Neuropsychologia, 43(3), 373-385.

Happé, F. i Frith, U. (2006). The weak coherence account: Detail-focused cognitive style in autism spectrum disorders. Journal of Autism and Developmental Disorders, 36(1), 525 .

Hedley, D., Brewer, N. i Young, R. (2011). Face recognition performance of individuals with Asperger syndrome on the Cambridge Face Memory Test. Autism Research, 4(6), 449455.

Hill, E., Berthoz, S. i Frith, U. (2004). Brief report: Cognitive processing of own emotions in individuals with autistic spectrum disorder and in their relatives. Journal of Autism and Developmental Disorders, 34(2), 229-235.

Humphreys, K., Minshew, N., Leonard, G. L. i Behrmann, M. (2007). A fine-grained analysis of facial expression processing in high-functioning adults with autism. Neuropsychologia, 45(4), 685-695.

Ichijo, E., Stantić, M., Chekroud, S., Murphy, J., Coll, M. P. i Bird, G. P. (2019, ožujak). Are 'neurotypical controls' really neurotypical? Individual differences in mental health traits in 'control' populations. Izlaganje na konferenciji Frontiers in Human Neuroscience, 4th International Conference on Educational Neuroscience, Abu Dhabi, Ujedinjeni Arapski Emirati.

Ihme, K., Dannlowski, U., Lichev, V., Stuhrmann, A., Grotegerd, D., Rosenberg, N. i Suslow, T. (2013). Alexithymia is related to differences in gray matter volume: A voxel-based morphometry study. Brain Research, 1491, 60-67.

Ishai, A., Schmidt, C. F. i Boesiger, P. (2005). Face perception is mediated by a distributed cortical network. Brain Research Bulletin, 67(1-2), 87-93. 
Joseph, R. M. i Tanaka, J. (2003). Holistic and part- based face recognition in children with autism. Journal of Child Psychology and Psychiatry, 44(4), 529-542.

Kanwisher, N. i Yovel, G. (2006). The fusiform face area: A cortical region specialized for the perception of faces. Philosophical Transactions of the Royal Society B: Biological Sciences, 361(1476), 2109-2128.

Kanwisher, N., McDermott, J. i Chun, M. M. (1997). The fusiform face area: A module in human extrastriate cortex specialized for face perception. Journal of Neuroscience, $17(11), 4302-4311$.

Langdell, T. (1978). Recognition of faces: An approach to the study of autism. Journal of Child Psychology and Psychiatry, 19(3), 255-268.

Leppänen, J. M. i Hietanen, J. K. (2004). Positive facial expressions are recognized faster than negative facial expressions, but why? Psychological Research, 69(1-2), 22-29.

Lombardo, M. V., Barnes, J. L., Wheelwright, S. J. i Baron-Cohen, S. (2007). Self-referential cognition and empathy in autism. PloS One, 2(9), e883.

McCarthy, G., Puce, A., Belger, A. i Allison, T. (1999). Electrophysiological studies of human face perception. II: Response properties of face-specific potentials generated in occipitotemporal cortex. Cerebral Cortex, 9(5), 431-444.

Murray, E., Hills, P. J., Bennetts, R. J. i Bate, S. (2018). Identifying hallmark symptoms of developmental prosopagnosia for non-experts. Scientific Reports, 8(1), 1690.

Nemiah, J., Freyberger, H. i Sifneos, P. E. (1976). Alexithymia: A view of the psychosomatic process. U: O. W. Hill (Ur.), Modern Tends in Psychosomatic Medicine (Vol. 3, str. 430-439). London, UK: Butterworths.

Parker, J. D., Taylor, G. J. i Bagby, R. M. (2001). The relationship between emotional intelligence and alexithymia. Personality and Individual Differences, 30(1), 107-115.

Parker, P. D., Prkachin, K. M. i Prkachin, G. C. (2005). Processing of facial expressions of negative emotion in alexithymia: The influence of temporal constraint. Journal of Personality, 73(4), 1087-1107.

Pelphrey, K. A., Sasson, N. J., Reznick, J. S., Paul, G., Goldman, B. D. i Piven, J. (2002). Visual scanning of faces in autism. Journal of Autism and Developmental Disorders, 32(4), 249-261.

Pierce, K., Haist, F., Sedaghat, F. i Courchesne, E. (2004). The brain response to personally familiar faces in autism: Findings of fusiform activity and beyond. Brain, 127(12), 27032716.

Pierce, K., Müller, R. A., Ambrose, J., Allen, G. i Courchesne, E. (2001). Face processing occurs outside the fusiformface area in autism: Evidence from functional MRI. Brain, 124(10), 2059-2073.

Pitcher, D., Walsh, V. i Duchaine, B. (2011). The role of the occipital face area in the cortical face perception network. Experimental Brain Research, 209(4), 481-493. 
Prkachin, G. C., Casey, C. i Prkachin, K. M. (2009). Alexithymia and perception of facial expressions of emotion. Personality and Individual Differences, 46(4), 412-417.

Rutherford, M. D., Clements, K. A. i Sekuler, A. B. (2007). Differences in discrimination of eye and mouth displacement in autism spectrum disorders. Vision Research, 47(15), 2099-2110.

Savez udruga za autizam Hrvatske. (1. travnja 2020). Učestalost autizma. Preuzeto s https://www.autizam-suzah.hr/autizam/\#question31548101963621

Schultz, R. T. (2005). Developmental deficits in social perception in autism: The role of the amygdala and fusiform face area. International Journal of Developmental Neuroscience, 23(2-3), 125-141.

Schweinberger, S. R., Pickering, E. C., Jentzsch, I., Burton, A. M. i Kaufmann, J. M. (2002). Event-related brain potential evidence for a response of inferior temporal cortex to familiar face repetitions. Cognitive Brain Research, 14(3), 398-409.

Shah, P., Bird, G. i Cook, R. (2016). Face processing in autism: Reduced integration of crossfeature dynamics. Cortex, 75, 113-119.

Shah, P., Gaule, A., Sowden, S., Bird, G. i Cook, R. (2015). The 20-item prosopagnosia index (PI20): A self-report instrument for identifying developmental prosopagnosia. Royal Society Open Science, 2(6), 140343.

Simmons, D. R., Robertson, A. E., McKay, L. S., Toal, E., McAleer, P. i Pollick, F. E. (2009). Vision in autism spectrum disorders. Vision Research, 49(22), 2705-2739.

Speranza, M., Loas, G., Wallier, J. i Corcos, M. (2007). Predictive value of alexithymia in patients with eating disorders: A 3-year prospective study. Journal of Psychosomatic Research, 63(4), 365-371.

Steeves, J. K., Culham, J. C., Duchaine, B. C., Pratesi, C. C., Valyear, K. F., Schindler, I. i Goodale, M. A. (2006). The fusiform face area is not sufficient for face recognition: Evidence from a patient with dense prosopagnosia and no occipital face area. Neuropsychologia, 44(4), 594-609.

Sussman, A. B., Petkova, K. i Todorov, A. (2013). Competence ratings in US predict presidential election outcomes in Bulgaria. Journal of Experimental Social Psychology, 49(4), 771-775.

Tanaka, J. W. i Farah, M. J. (1993). Parts and wholes in face recognition. The Quarterly Journal Of Experimental Psychology, 46(2), 225-245.

Tanaka, J. W., Curran, T., Porterfield, A. L. i Collins, D. (2006). Activation of preexisting and acquired face representations: The N250 event-related potential as an index of face familiarity. Journal of Cognitive Neuroscience, 18(9), 1488-1497.

Tarr, M. J. i Gauthier, I. (2000). FFA: A flexible fusiform area for subordinate-level visual processing automatized by expertise. Nature Neuroscience, 3(8), 764-769.

Taylor, G. J., Bagby, R. M., Ryan, D. P. i Parker, J. D. (1990). Validation of the alexithymia construct: A measurement-based approach. The Canadian Journal of Psychiatry, 35(4), 290-297. 
Taylor, G. J., Ryan, D. i Bagby, M. (1985). Toward the development of a new self-report alexithymia scale. Psychotherapy and Psychosomatics, 44(4), 191-199.

Taylor, M. J., Batty, M. i Itier, R. J. (2004). The faces of development: A review of early face processing over childhood. Journal of Cognitive Neuroscience, 16(8), 1426-1442.

Thomas, C., Avidan, G., Humphreys, K., Jung, K. J., Gao, F. i Behrmann, M. (2009). Reduced structural connectivity in ventral visual cortex in congenital prosopagnosia. Nature Neuroscience, 12(1), 29-31.

Wallace, S., Coleman, M. i Bailey, A. (2008a). Face and object processing in autism spectrum disorders. Autism Research, 1(1), 43-51.

Wallace, S., Coleman, M. i Bailey, A. (2008b). An investigation of basic facial expression recognition in autism spectrum disorders. Cognition and Emotion, 22(7), 1353-1380.

Wang, A. T., Dapretto, M., Hariri, A. R., Sigman, M. i Bookheimer, S. Y. (2004). Neural correlates of facial affect processing in children and adolescents with autism spectrum disorder. Journal of the American Academy of Child and Adolescent Psychiatry, 43(4), 481-490.

Webb, S. J., Neuhaus, E. i Faja, S. (2017). Face perception and learning in autism spectrum disorders. The Quarterly Journal of Experimental Psychology, 70(5), 970-986.

Yin, R. K. (1969). Looking at upside-down faces. Journal of Experimental Psychology, 81(1), 141-145.

Young, A. W., Hellawell, D. i Hay, D. C. (1987). Configurational information in face perception. Perception, 16(6), 747-759.

\title{
Face Perception in Autism Spectrum Disorder: From Singular to Modular Perspectives
}

\begin{abstract}
In the last few decades, the media have continuously reported on the increased number of diagnosis of Autism Spectrum Disorder (ASD). This systematic review looks at the evolution of research on face perception, one of the characteristics of ASD, in the light of recently reported prevalence of alexythimia comorbidity, as well as improved statistical methods in cognitive research. We review the literature on behavioural face perception testing in autism, showing the importance of a prevalent comorbidity of alexythimia, as well as neural evidence showing the importance of differential eye gaze patterns in autism for data analysis. We suggest outstanding questions in the field in order to improve the integration of people with ASD and alexithymia into the educational and social contexts.
\end{abstract}

Keywords: autism, alexythimia, face perception, visual perception, fusiform gyrus, amygdala

Primljeno: 12.10.2019. 